\title{
Polymers with Oligoorganosiloxane Side Chains as Material for Oxygen Permeable Membranes
}

\author{
Yuhsuke KaWAKAMI, ${ }^{*}$ Hiroo KARASAWA, Toshiki AOKI, \\ Yoshihiro YamamURA, Hirofumi HiSADA, \\ and Yuya YAMASHITA \\ Department of Synthetic Chemistry, Faculty of Engineering, \\ Nagoya University, Chikusa, Nagoya 464, Japan
}

(Received March 15, 1985)

\begin{abstract}
Styrene and methacrylate type monomers having oligoorganosiloxane substituents were synthesized, and the properties of the polymers therefrom as material for oxygen permeable membranes were evaluated by gas chromatographic method. Homopolymers with short siloxane chains were found to be better than those with long branches in selectivity in permeation and mechanical strength. Introduction of fluorine atoms into polymer structure did not improve the selectivity in permeation.
\end{abstract}

KEY WORDS Oligosiloxane / Ultrasonic Irradiation / Macromer / Fluoro Siloxane / Ring-Opening Polymerization / Vinyl Polymerization / Comb Polymer / Graft Copolymer / Oxygen Permeation / Permselective Membrane /

Recently, much attention has been paid to the selective gas permeable membranes. As material for oxygen permselective membrane, at least three basic requirements must be satisfied: 1) high permeability coefficient $\left(P_{\mathrm{O}_{2}}\right) 2$ ) high selectivity $\left[\alpha=\left(p_{\mathrm{O}_{2,2}} / p_{\mathrm{N}_{2,2}}\right) /\left(p_{\mathrm{O}_{2,1}} / p_{\mathrm{N}_{2,1}}\right)\right.$ $\simeq P_{\mathrm{O}_{2}} / P_{\mathrm{N}_{2}}$, and 3) self-supporting property. We have reported poly( $p$-disiloxane substituted styrene)s as good self-supporting material for oxygen permeable membranes of considerably high separation factor $[\alpha=2.8$ for poly $(p$-pentamethyldisiloxanylstyrene $)]{ }^{1} \quad \mathrm{We}$ have been also interested in polydimethylsiloxane (PDMS) graft copolymers as surface modifying material of hydrophilic polymers. $^{2-5}$ Such polymers might be also of interest as oxygen permeable membrane material, because PDMS has high $P_{\mathrm{O}_{2}}$ although the selectivity in permeation and mechanical strength are low. The disadvantage about the mechanical strength has been overcome by putting the PDMS chain into block ${ }^{6}$ or crosslinked $^{7}$ copolymers; however, the selectivity $\alpha$ remained still low. Since the reason for the low selectivity was suspected to be because of the inherent nature of the rather long PDMS chains in these copolymers, experiments were carried out to study the effects of the length of oligoorganosiloxane side chains on back bone polymers on the film forming property, and permeability and selectivity in oxygen permeation.

Up till now, many perfluorinated compounds have been known to show high solubility of oxygen, and some of them are used as artificial blood substitutes. ${ }^{8}$ In designing oxygen permeable membranes, the modification of polymer structure by fluorine atoms seems quite interesting.

In this article, the syntheses of oligoorganosiloxanes having various vinyl-polymerizable groups (including macromers) and the properties of the polymers therefrom as material for oxygen permselective membranes are reported. 


\section{EXPERIMENTAL}

The monomers were synthesized basically by reacting lithium silanolates with vinylpolymerizable chlorosilane compounds. Lithium trimethylsilanolate (LTMS), lithium 3,3,3-trifluoropropyldimethylsilanolate (LFMS), $p$-dimethylchlorosilylstyrene ( $\mathrm{SSiCl}$ ), $p$-(3,3,3-trifluoropropyl)methylchlorosilyl styrene (FSiCl), 5-dimethylchlorosilylpentyl methacrylate $(\mathrm{MSiCl})$ were synthesized according to reported methods. ${ }^{1,2}$ Analyses of some new disiloxane monomers were reported. ${ }^{1}$ The synthetic routes to styrenyl, methacrylyl, fluoro substituted styrenyl, and $p$ vinylbenzyl monomers are shown in Schemes $1-4$.

Other monomers used in this study are 3-[3'bis(trimethylsiloxy)methylsilylpropoxy]-2hydroxypropyl methacrylate (MS3) and 2-perfluoroalkylethyl acrylate (FA) having the structure $\quad \mathrm{CH}_{2}=\mathrm{CHCO}_{2} \mathrm{CH}_{2} \mathrm{CH}_{2}\left(\mathrm{CF}_{2}\right)_{n^{-}}$ $\mathrm{CF}_{3}(n=8.6)$. The chemical shifts are given as $\delta$ value in ppm unit using TMS as an internal standard. Vinyl and aromatic protons of S3, $\mathrm{S} 4, \mathrm{~S} 5, \mathrm{~S} 8$, and $p$-(5-chlorohexamethyltrisiloxanyl)styrene appeared at identical positions with those of S1. The signals of methacrylyl protons and methylene protons not linking directly to silicon atom of M5 and M8 were observed at identical positions with those of M2. Benzyl methylene, vinyl, and aromatic protons of B2, B3, B4, B5 were found at identical positions with those of $\mathrm{B} 1$.

Polymerizations were carried out typically in tetrahydrofuran (THF) using $\alpha, \alpha^{\prime}$-azobisisobutyronitrile (AIBN) as an initiator. The polymers were purified by reprecipitation from THF into methanol. The molecular weights and molecular weight distribution were determined on GPC correlating to standard polystyrene. When necessary, some modifications were made for the solvent systems.

$T_{\mathrm{g}} \mathrm{s}$ were measured on a Perkin-Elmer model DSC-2 differential scanning calorimeter.

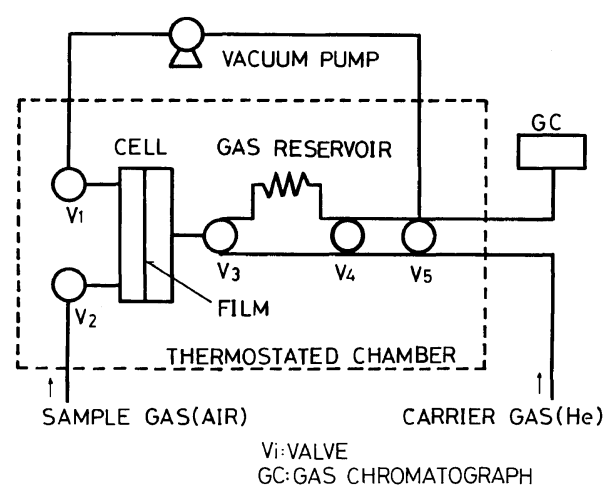

Figure 1. The schematic diagram of gas permeation rate apparatus.

Polymer films were prepared by casting the polymer solution in THF $(5 \%)$ on clean glass surface and evaporating the solvent under controlled conditions; the solvent was usually evaporated at $20^{\circ} \mathrm{C}$ during $48 \mathrm{~h}$. The formed films were detached from the glass surface by immersing in water, and dried between filter papers under vacuum for $48 \mathrm{~h}$. The polymer films, whose $T_{\mathrm{g}}$ is higher than $50^{\circ} \mathrm{C}$, were annealed at $50^{\circ} \mathrm{C}$ for $24 \mathrm{~h}$. The thickness of the films was about $80 \mu \mathrm{m}$. The permeability and selectivity in permeation were evaluated for supplied air by gas chromatographic method at $25^{\circ} \mathrm{C}$. The flow diagram is shown in Figure 1.

\section{p-Trimethylsilylstyrene (S1)}

To $p$-vinylphenylmagnesium chloride prepared from $\mathrm{Mg}(13.6 \mathrm{~g}, 148 \mathrm{mmol})$ and $p$ chlorostyrene $(10.5 \mathrm{~g}, 75 \mathrm{mmol})$ in THF $(85 \mathrm{ml})$, a slight excess of trimethylchlorosilane was added dropwise at $0^{\circ} \mathrm{C}$. The usual workup, distillation, and purification by silica gel column chromatography gave the product in $81 \%$ yield. bp $55-57^{\circ} \mathrm{C} \quad(0.2 \mathrm{mmHg}) .{ }^{1} \mathrm{H}$ $\operatorname{NMR}\left(\mathrm{CCl}_{4}\right) \delta=0.23\left(\mathrm{~s}, 9 \mathrm{H}, \mathrm{SiCH}_{3}\right), 5.16(\mathrm{q}$,

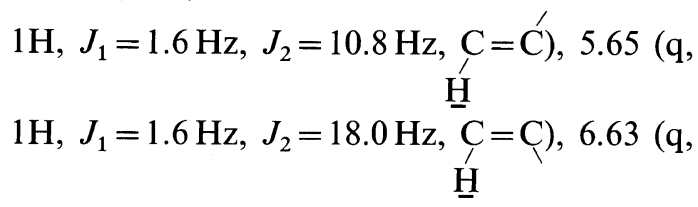




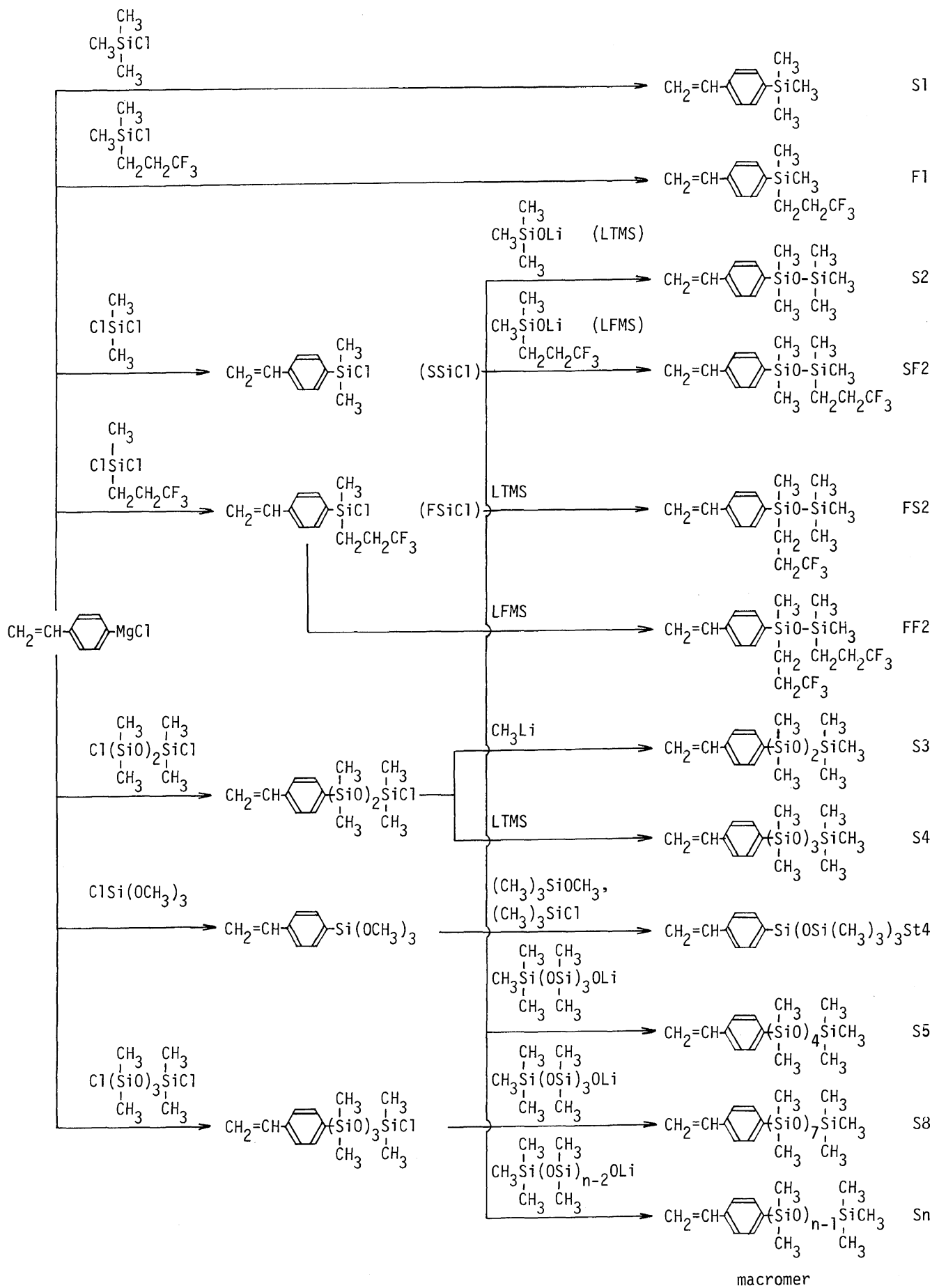

Scheme 1. Synthetic routes to styrene type oligosiloxane monomers. 


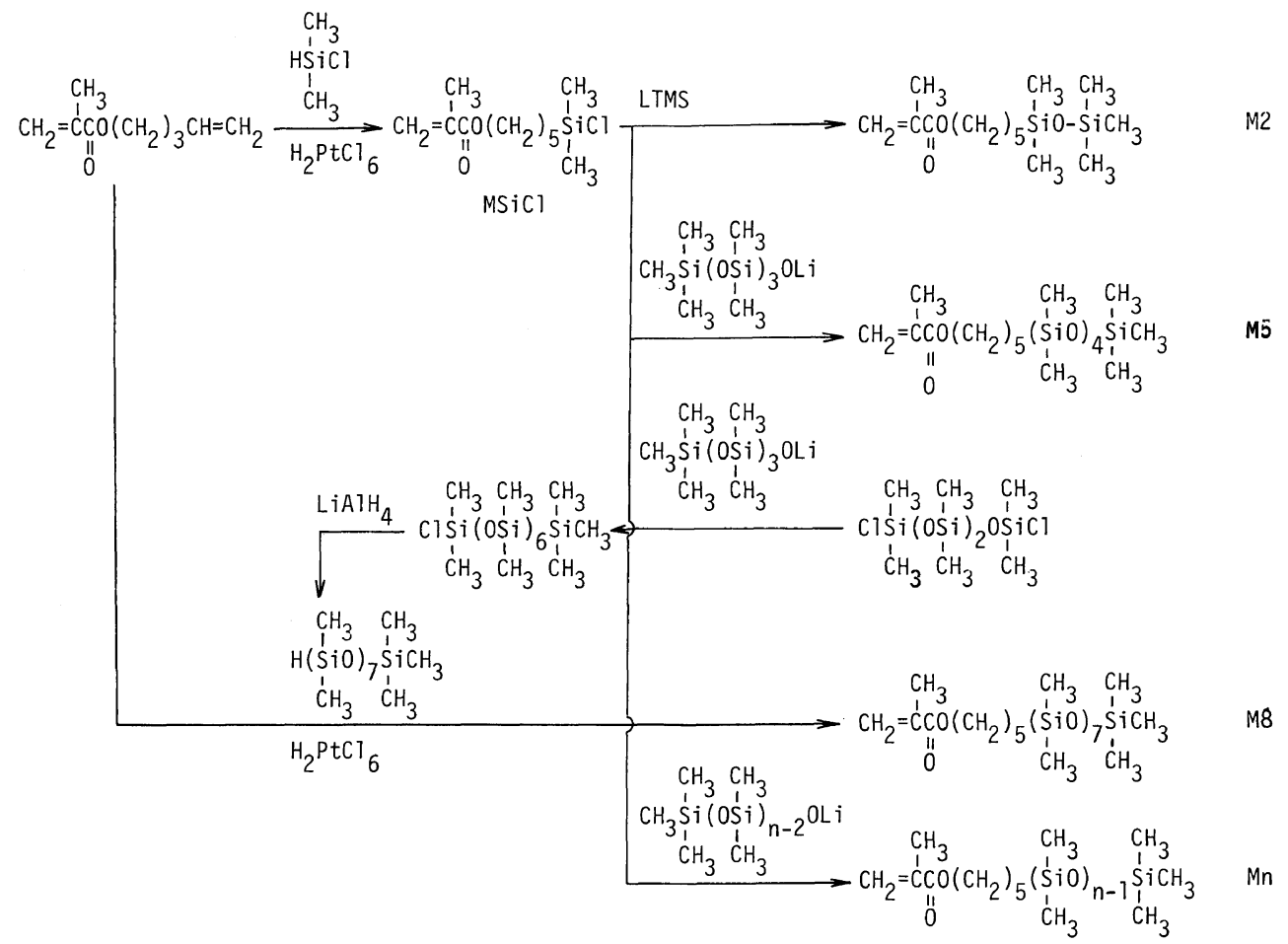

Scheme 2. Synthetic routes to methacrylate type oligosiloxane monomers.

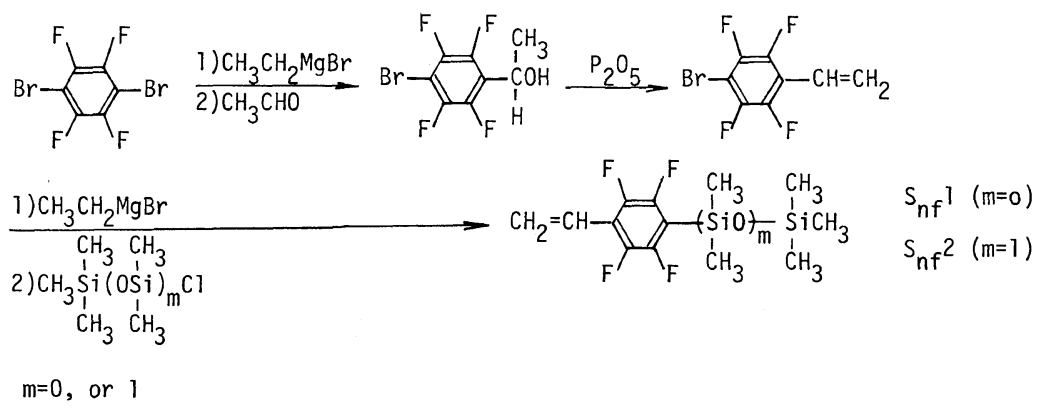

Scheme 3. Synthetic route to fluoro-substituted styrene type oligosiloxane monomers.

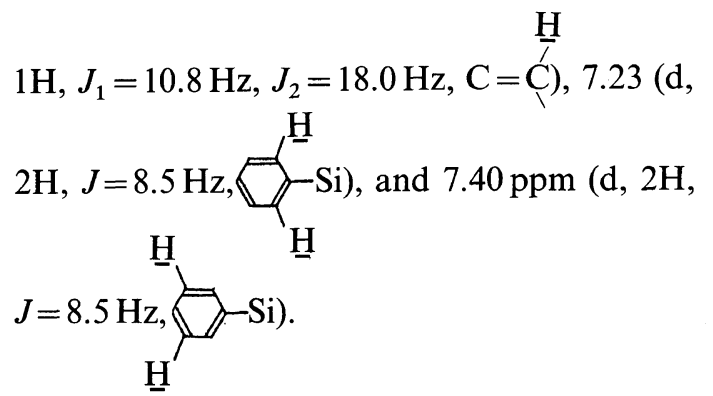

p-(3,3,3-Trifluoropropyl)dimethylsilylstyrene (F1) $p$-Vinylphenylmagnesium chloride was similarly reacted with 3,3,3-trifluoropropyldimethylchlorosilane. $70 \%$ yield. ${ }^{1} \mathrm{H}$ NMR $\left(\mathrm{CCl}_{4}\right) \delta=0.32\left(\mathrm{~s}, 6 \mathrm{H}, \mathrm{SiC}_{3}\right), 0.77-1.17(\mathrm{~m}$, $\left.2 \mathrm{H}, \mathrm{SiC}_{2}\right), 1.30-2.38\left(\mathrm{~m}, 2 \mathrm{H}, \mathrm{CH}_{2} \mathrm{CF}_{3}\right)$, $5.21\left(\mathrm{q}, 1 \mathrm{H}, J_{1}=10.6 \mathrm{~Hz}, J_{2}=1.5 \mathrm{~Hz}, \mathrm{C}=\mathbf{C}^{\prime}\right.$ ), 


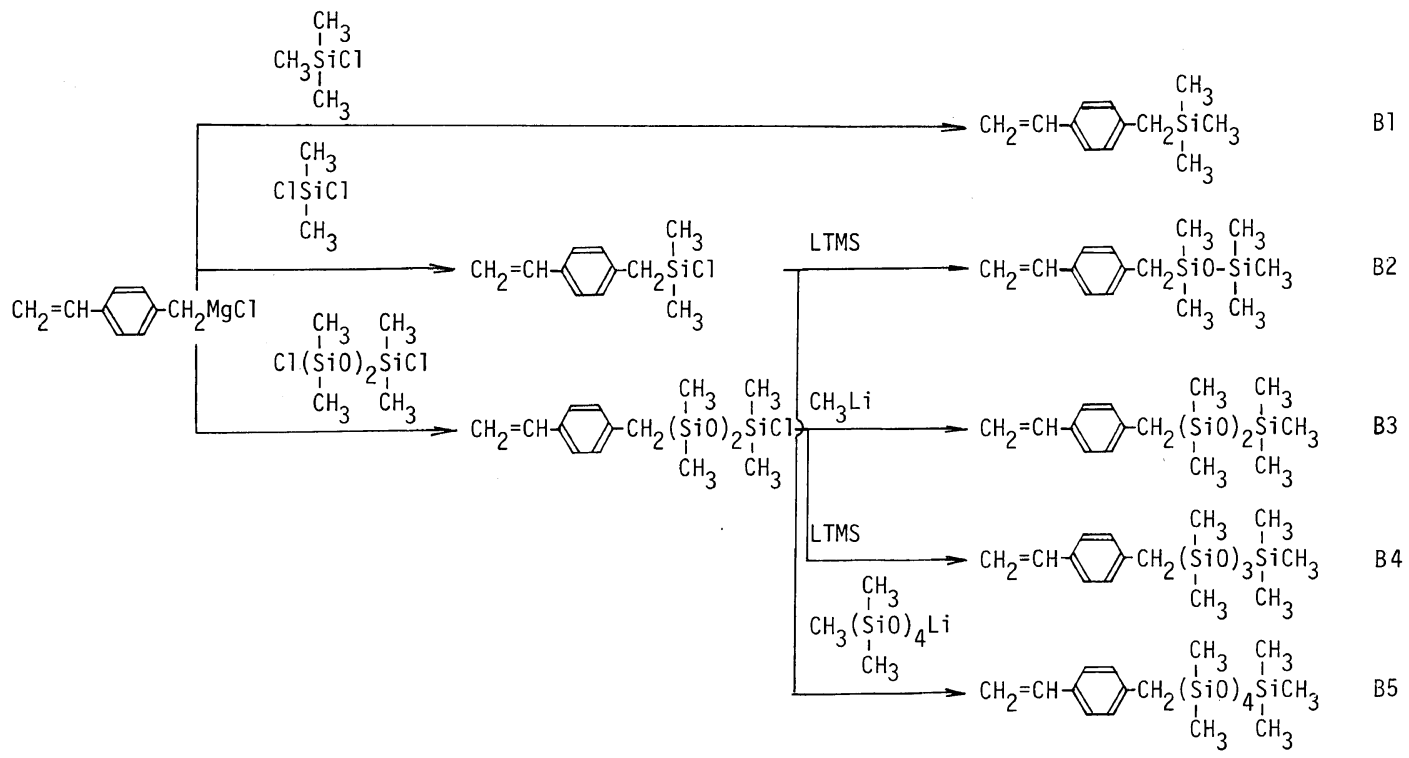

Scheme 4. Synthetic routes to $p$-vinylbenzyl type oligosiloxane monomers.

$\frac{\mathrm{H}}{\mathrm{H}} \quad$ bromide in ethyl ether $(150 \mathrm{ml})$ at $-78-0^{\circ} \mathrm{C}$. $5.69\left(\mathrm{q}, 1 \mathrm{H}, J_{1}=10.6 \mathrm{~Hz}, J_{2}=1.5 \mathrm{~Hz}, \grave{\mathrm{C}}=\mathrm{C}\right), \quad 95 \%$ yield. The product was purified by col$6.67\left(\mathrm{q}, \quad 1 \mathrm{H}, \quad J_{1}=19.0 \mathrm{~Hz}, \quad J_{2}=10.6 \mathrm{~Hz}, \quad \mathrm{umn}\right.$ chromatography. ${ }^{1} \mathrm{H} \quad \mathrm{NMR}\left(\mathrm{CCl}_{4}\right)$ $, \underline{\mathrm{H}} \quad \underline{\mathrm{H}}=0.07\left(\mathrm{~s}, 9 \mathrm{H}, \mathrm{Si}\left(\mathrm{C}_{3}\right)_{3}\right), 0.09 \quad(\mathrm{~s}, 6 \mathrm{H}$, $\mathrm{C}=\mathrm{C}), 7.27(\mathrm{~d}, 2 \mathrm{H}, J=8.6 \mathrm{~Hz}$, $-\mathrm{Si})$, and $\left.\mathrm{OSi}\left(\mathrm{C}_{-}\right)_{2}\right), 0.33 \mathrm{ppm}\left(\mathrm{s}, 6 \mathrm{H}, \approx-\mathrm{Si}\left(\mathrm{C}_{3}\right)_{2}\right)$. $7.41 \mathrm{ppm}\left(\mathrm{d}, 2 \mathrm{H}, J=8.6 \mathrm{~Hz}, \underset{\underline{H}}{\underline{H}}-\mathrm{Si}^{\mathrm{H}}\right)$. p-Nonamethyltetrasiloxan-1-ylstyrene (S4) p-(5-Chlorohexamethyltrisiloxanyl)styrene ( $20 \mathrm{~g}, 58 \mathrm{mmol})$ was reacted with a slight excess of LTMS. Usual work-up and column chro-

\section{p-(5-Chlorohexamethyltrisiloxanyl)styrene}

$p$-Vinylphenylmagnesium chloride was added dropwise to $70 \%$ excess 1,5-dichlorohexamethyltrisiloxane ${ }^{9}(35.5 \mathrm{~g}, 128 \mathrm{mmol})$ at $60^{\circ} \mathrm{C}$ during $1.5 \mathrm{~h}$. After removing the formed salt, the product was isolated by distillation in $42 \%$ yield. bp $105^{\circ} \mathrm{C}(0.20 \mathrm{mmHg}) .{ }^{1} \mathrm{H}$ NMR $\left(\mathrm{CCl}_{4}\right) \delta=0.15 \quad\left(\mathrm{~s}, \quad 6 \mathrm{H}, \quad \mathrm{OSi}\left(\mathrm{CH}_{3}\right)_{2}\right), \quad 0.34$ $\left(\mathrm{s}, 6 \mathrm{H}, \square-\mathrm{Si}\left(\mathrm{CH}_{3}\right)_{2}\right)$, and $0.50 \mathrm{ppm}(\mathrm{s}, 6 \mathrm{H}$, $\left.\mathrm{ClSi}\left(\mathrm{CH}_{3}\right)_{2}\right)$.

p-Heptamethyltrisiloxan-1-ylstyrene (S3)

p-(5-Chlorohexamethyltrisiloxanyl)styrene $(20 \mathrm{~g}, 58 \mathrm{mmol})$ was methylated with slight excess methyllithium or methylmagnesium matography afforded the product in $85 \%$ yield. ${ }^{1} \mathrm{H} \quad \mathrm{NMR}\left(\mathrm{CCl}_{4}\right) \quad \delta=0.08 \quad(\mathrm{~s}, \quad 21 \mathrm{H}$, $\left.\mathrm{OSiCH}_{3}\right)$ and $0.33 \mathrm{ppm}\left(\mathrm{s}, 6 \mathrm{H}, \square-\mathrm{Si}\left(\mathrm{CH}_{3}\right)_{2}\right)$. S4 could be synthesized alternatively by methylation of $p$-(7-chlorooctamethyltetrasiloxanyl)styrene by methyllithium or methylmagnesium bromide.

\section{p-Trimethoxysilylstyrene}

Trimethoxychlorosilane $(8.5 \mathrm{~g}, 54 \mathrm{mmol})$ was added dropwise at $50^{\circ} \mathrm{C}$ during $20 \mathrm{~min}$ to $p$-vinylphenylmagnesium chloride $(36 \mathrm{mmol})$ in THF $(40 \mathrm{ml})$. The reaction mixture was warmed to $60-65^{\circ} \mathrm{C}$, and reacted for $3 \mathrm{~h}$. After evaporating the solvent, dry ethyl ether $(90 \mathrm{ml})$ was added, and the formed salt was 
removed by filtration under $\mathrm{N}_{2}$. Distillation gave the product in $36 \%$ yield. bp $61^{\circ} \mathrm{C}$ $(0.15 \mathrm{~mm} \mathrm{Hg}) .{ }^{1} \mathrm{H} \mathrm{NMR}\left(\mathrm{CCl}_{4}\right) \delta=3.40$ (s, $9 \mathrm{H}$, $\left.\mathrm{CH}_{3}\right), 5.05\left(\mathrm{q}, 1 \mathrm{H}, J_{1}=10.8 \mathrm{~Hz}, J_{2}=1.5 \mathrm{~Hz}\right.$, $\left.\mathrm{C}=C^{\prime}\right), 5.60\left(\mathrm{q}, 1 \mathrm{H}, J_{1}=17.2 \mathrm{~Hz}, J_{2}=1.5 \mathrm{~Hz}\right.$, H

H

$\grave{C}_{\mathrm{C}}=\stackrel{\mathrm{C}}{)}, 6.50\left(\mathrm{q}, 1 \mathrm{H}, J_{1}=10.8 \mathrm{~Hz}, J_{2}=17.2 \mathrm{~Hz}\right.$,

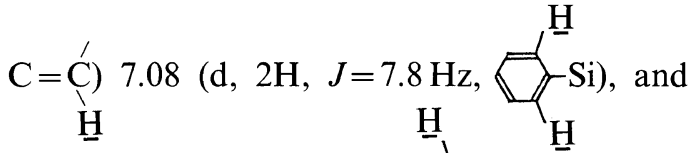

$7.40 \mathrm{ppm}\left(\mathrm{d}, 2 \mathrm{H}, J=7.8 \mathrm{~Hz}, \mathrm{~J}_{-\mathrm{Si}}\right)$.

$\underline{\mathrm{H}}^{\prime}$

$p$-[Tris(trimethylsiloxy)silyl]styrene (St4)

The mixture of $p$-trimethoxysilylstyrene $(0.9 \mathrm{~g}, 4 \mathrm{mmol})$, trimethylchlorosilane $(1.3 \mathrm{~g}$, $12 \mathrm{mmol})$, and trimethylmethoxysilane $(1.3 \mathrm{~g}$, $12 \mathrm{mmol})$ was added dropwise to water $(4.4 \mathrm{ml})$ and diethyl ether $(4.2 \mathrm{ml})$ mixture at $15^{\circ} \mathrm{C}$ during $1 \mathrm{~h}$, and reacted over night. The product was extracted with ether, and purified by column chromatography. $25 \%$ yield. The compound tended to adsorb on silica gel. ${ }^{1} \mathrm{H}$ $\operatorname{NMR}\left(\mathrm{CCl}_{4}\right) \delta=0.20\left(\mathrm{~s}, 27 \mathrm{H}, \mathrm{SiCH}_{3}\right), 5.25(\mathrm{q}$, $\left.1 \mathrm{H}, J_{1}=10.8 \mathrm{~Hz}, J_{2}=1.5 \mathrm{~Hz}, \mathrm{C}=\mathrm{C}^{\prime}\right), 5.73(\mathrm{q}$, H

$\left.1 \mathrm{H}, J_{1}=17.2 \mathrm{~Hz}, J_{2}=1.5 \mathrm{~Hz}, \underset{\mathrm{C}}{\mathrm{C}}=\mathrm{C}\right), 6.72(\mathrm{q}$, $\left.1 \mathrm{H}, J_{1}=10.8 \mathrm{~Hz}, J_{2}=17.2 \mathrm{~Hz}, \mathrm{C}=\stackrel{\underline{\mathrm{H}}}{\mathrm{C}}\right), 7.33(\mathrm{~d}$, $2 \mathrm{H}, J=7.8 \mathrm{~Hz}$,

p-Undecamethylpentasiloxan-1-ylstyrene (S5)

To LTMS $(3.17 \mathrm{~g}, 32 \mathrm{mmol})$ in THF $(80 \mathrm{ml})$, hexamethylcyclotrisiloxane $\quad\left(\mathrm{D}_{3}\right) \quad(6.68 \mathrm{~g}$, $33 \mathrm{mmol})$ in THF $(40 \mathrm{ml})$ was added at $-78^{\circ} \mathrm{C}$. After the addition, the reaction system was warmed up to $0^{\circ} \mathrm{C}$, and reacted for further $16 \mathrm{~h}$. To this reaction mixture, $\mathrm{SSiCl}^{2}(5.90 \mathrm{~g}$, $30 \mathrm{mmol})$ in THF $(20 \mathrm{ml})$ was added and reacted for $12 \mathrm{~h}$. The usual work-up and column chromatography gave the product in $92 \%$ yield. ${ }^{1} \mathrm{H} \quad \mathrm{NMR}\left(\mathrm{CCl}_{4}\right) \quad \delta=0.07 \quad(\mathrm{~s}, \quad 9 \mathrm{H}$, $\left.\mathrm{Si}\left(\mathrm{CH}_{3}\right)_{3}\right), 0.09$ (s, $\left.18 \mathrm{H}, \quad \mathrm{OSi}\left(\mathrm{CH}_{3}\right)_{2}\right)$, and

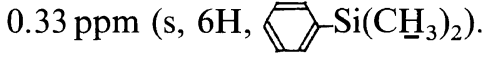

\section{p-(7-Chlorooctamethyltetrasiloxanyl)styrene}

similarly to the synthesis of $p$-(5-chlorohexamethyltrisiloxanyl)styrene. The product was obtained in $39 \%$ yield. bp $111^{\circ} \mathrm{C} \quad(0.15$ mmHg). ${ }^{1} \mathrm{H}$ NMR $\delta=\left(\mathrm{CDCl}_{3}\right) 0.12(\mathrm{~s}, 12 \mathrm{H}$, $\left.\mathrm{OSi}\left(\mathrm{C}_{3}\right)_{2}\right), 0.33\left(\mathrm{~s}, 6 \mathrm{H}, \square \mathrm{Si}\left(\mathrm{C}_{3}\right)_{2}\right)$, and $0.50 \mathrm{ppm}\left(\mathrm{s}, 6 \mathrm{H}, \mathrm{ClSi}\left(\mathrm{C}_{3}\right)_{2}\right)$.

\section{p-Heptadecamethyloctasiloxan-1-ylstyrene}

This monomer was synthesized similarly to S5 using $p$-(7-chlorooctamethyltetrasiloxanyl)styrene in place of $\mathrm{SSiCl} .95 \%$ yield. ${ }^{1} \mathrm{H} \mathrm{NMR}\left(\mathrm{CDCl}_{3}\right) \delta=0.06\left(\mathrm{~s}, 9 \mathrm{H}, \mathrm{Si}\left(\mathrm{CH}_{3}\right)_{3}\right)$, 0.09 (s, 36H, OSi $\left.\left(\mathrm{CH}_{3}\right)_{2}\right)$, and $0.33 \mathrm{ppm}$ (s, $6 \mathrm{H}$, $\left.-\mathrm{Si}\left(\mathrm{C}_{3}\right)_{2}\right)$.

p-Polydimethylsiloxan-1-yl-styrene $(\mathrm{Sn})$ (macromer)

To the polymerization product of $\mathrm{D}_{3}$ $(15.58 \mathrm{~g}, 70 \mathrm{mmol})$ initiated by LTMS $(0.385 \mathrm{~g}$, $4 \mathrm{mmol})$ at $-78^{\circ} \mathrm{C}$ in $\mathrm{THF}$ and reacted for $24 \mathrm{~h}$ at $0^{\circ} \mathrm{C}$, THF $(20 \mathrm{ml})$ solution of $\mathrm{SSiCl}$ $(1.18 \mathrm{~g}, 6 \mathrm{mmol})$ was added dropwise at the temperature. After the usual work-up and purification by column chromatography, the macromer $\mathrm{Sn}$ was obtained in $85 \%$ yield. $M_{n}=7.1 \times 10^{3} \quad(\overline{\mathrm{DP}}=94), \quad M_{w}=7.5 \times 10^{3}$, $M_{w} / M_{n}=1.06$. This macromer is abbreviated as $\mathrm{S} 94$.

Comments will be made on the order of the introduction of double bond and oligosiloxane side chain in results and discussion section.

\section{5-Pentamethyldisiloxanylpentyl methacrylate (M2)}

LTMS $(0.24 \mathrm{~g}, 2.5 \mathrm{mmol})$ was reacted. with 
$\mathrm{MSiCl}^{2}(0.63 \mathrm{~g}, 2.5 \mathrm{mmol})$ at room temperature in THF $(5 \mathrm{ml})$. The usual work-up and purification by column chromatography gave the product in $91 \%$ yield. ${ }^{1} \mathrm{H} \mathrm{NMR}\left(\mathrm{CCl}_{4}\right)$ $\delta=0.14$ (s, $15 \mathrm{H}, \mathrm{SiCH}_{3}$ ), $0.33-0.82$ (broad, $\left.2 \mathrm{H}, \mathrm{CH}_{2} \mathrm{Si}\right), 1.00-1.83\left(\mathrm{~m}, 6 \mathrm{H},\left(\mathrm{CH}_{2}\right)_{3}\right), 1.92$ (s, $\left.3 \mathrm{H}, \mathrm{CH}_{3}\right), 4.03\left(\mathrm{t}, 2 \mathrm{H}, J=6.1 \mathrm{~Hz}, \mathrm{OCH}_{2}\right)$, $5.60(\mathrm{~m}, 1 \mathrm{H}, \mathrm{C} \underline{\mathrm{H}}=)$, and $6.08 \mathrm{ppm}(\mathrm{m}, 1 \mathrm{H}$, $\mathrm{C} \underline{\mathrm{H}}=)$.

\section{5-(Undecamethylpentasiloxan-1-yl)pentyl methacrylate (M5)}

This monomer was synthesized similarly to S5 using $\mathrm{MSiCl}$ as the terminating agent in place of SSiCl. The usual work-up and purification gave the product in $85 \%$ yield. ${ }^{1} \mathrm{H}$ $\mathrm{NMR}\left(\mathrm{CCl}_{4}\right) \delta=0.15,0.17,0.19$ (three s, $33 \mathrm{H}$, $\mathrm{SiCH}_{3}$ ), and $0.33-0.73 \mathrm{ppm}\left(\mathrm{m}, 2 \mathrm{H}, \mathrm{SiCH}_{2}\right)$.

\section{1-Hydroheptadecamethyloctasiloxane}

To lithium nonamethyltetrasiloxanolate prepared from LTMS $(0.96 \mathrm{~g}, 10 \mathrm{mmol})$ and $\mathrm{D}_{3}(2.23 \mathrm{~g}, 10 \mathrm{mmol})$ in $\mathrm{THF}(35 \mathrm{ml})$ at $-78^{\circ} \mathrm{C}$, was added dropwise 1,7-dichlorooctamethyltetrasiloxane $(5.22 \mathrm{ml}, 15 \mathrm{mmol})$ in THF $(20 \mathrm{ml})$ at room temperature during $1 \mathrm{~h}$. After the reaction mixture was cooled down to dry-ice temperature, lithium aluminum hydride $(0.88 \mathrm{~g}, 22 \mathrm{mmol})$ in THF $(20 \mathrm{ml})$ was added dropwise during $1 \mathrm{~h}$. The reaction mixture was allowed to warm up gradually to room temperature. After evaporating the solvent, $n$-hexane was added, and the formed salt was removed by centrifugation. Distillation after removal of $n$-hexane gave the product in $38 \%$ yield. bp $99^{\circ} \mathrm{C} \quad(0.12 \mathrm{mmHg}) . \quad{ }^{1} \mathrm{H}$ $\operatorname{NMR}\left(\mathrm{CDCl}_{3}\right) \delta=0.07\left(\mathrm{~s}, 45 \mathrm{H}, \mathrm{OSiCH}_{3}\right), 0.10$ (s, 6H, $\mathrm{HSi}\left(\mathrm{C}_{3}\right)_{2}$ ), and $4.67 \mathrm{ppm}$ (hept, $1 \mathrm{H}$, $\mathrm{Si} \underline{\mathrm{H}})$.

\section{5-(Heptadecamethyloctasiloxan-1-yl)pentyl methacrylate (M8)}

To chloroplatinic acid $\left(\mathrm{H}_{2} \mathrm{PtCl}_{6} \cdot 6 \mathrm{H}_{2} \mathrm{O}\right.$, $0.05 \mathrm{~g})$ dissolved in 2-propanol $(0.3 \mathrm{ml})$, 4pentenyl methacrylate $(1.85 \mathrm{~g}, 12 \mathrm{mmol})$ was added, and the mixture was warmed to $60^{\circ} \mathrm{C}$.
Small amounts of 1-hydroheptadecamethyloctasiloxane were added to the mixture, and the reaction system was warmed to $100^{\circ} \mathrm{C}$. Immediately after the activation of chloroplatinic acid occurred, which could be judged by the change in its color from brown to black, the system was cooled down again to $60^{\circ} \mathrm{C}$, and the rest of 1-hydroheptadecamethyloctasiloxane $(62 \mathrm{~g}, 10.4 \mathrm{mmol})$ was added dropwise at the temperature, and reacted for $6 \mathrm{~h}$. After removal of 2-propanol by evacuation, the product was isolated by chromatography. $76^{\circ} \%$ yield. ${ }^{1} \mathrm{H} \mathrm{NMR}\left(\mathrm{CCl}_{4}\right) \delta=0.10(\mathrm{~s}, 51 \mathrm{H}$, $\left.\mathrm{SiCH}_{3}\right)$, and $0.33-0.67 \mathrm{ppm}\left(\mathrm{m}, 2 \mathrm{H}, \mathrm{SiC}_{2}\right)$.

\section{5-(Polydimethylsiloxan-1-yl)pentyl methacryl- ate $(\mathrm{Mn})$}

Methacrylate macromer $\mathrm{Mn}$ was synthesized similarly to $\mathrm{Sn}$ using $\mathrm{MSiCl}$ as the terminating agent in the polymerization of $D_{3}$. Terminating reactions were carried out under ultrasonic irradiation.

\section{Pentafluorostyrene $\left(S_{n f}\right)$}

Bromopentafluorobenzene $\quad(4.20 \mathrm{~g}, \quad 17$ $\mathrm{mmol})$ was added dropwise to $\mathrm{THF}(16 \mathrm{ml})$ solution of ethylmagnesium bromide $(30 \mathrm{mmol})$ at $0^{\circ} \mathrm{C}$, and reacted for $1 \mathrm{~h}$ at room temperature. After removal of THF, the reaction system was diluted with ether $(56 \mathrm{ml})$, and reacted with acetaldehyde $(2.5 \mathrm{ml}$, $45 \mathrm{mmol})$ in ethyl ether $(17 \mathrm{ml})$ at $15^{\circ} \mathrm{C}$ for $16 \mathrm{~h}$. After decomposing the reaction mixture with $1 \mathrm{~N} \mathrm{HCl}(30 \mathrm{ml})$, the product was extracted with ethyl ether and the crude product, after evaporating the solvent, was dehydrated with phosphorus pentoxide $(1.90 \mathrm{~g})$ in the presence of hydroquinone $(0.14 \mathrm{~g})$ at $160^{\circ} \mathrm{C}$ to give the product. bp $72.0^{\circ} \mathrm{C}(87.5 \mathrm{mmHg})$. $71.1 \%$ yield. ${ }^{1} \mathrm{H}$ NMR was identical with the authentic sample.

\section{4-Bromo-2,3,5,6-tetrafluorostyrene}

To THF $(130 \mathrm{ml})$ solution of 1,4-dibromotetrafluorobenzene $(13.3 \mathrm{~g}, 43 \mathrm{mmol})$, ethylmagnesium bromide $(48 \mathrm{mmol})$ in THF $(25 \mathrm{ml})$ 
was added dropwise at room temperature, and reacted for $1 \mathrm{~h}$ at the temperature. After removal of THF, the reaction system was diluted with ethyl ether $(150 \mathrm{ml})$, are reacted with acetaldehyde $(9.54 \mathrm{~g}, 275 \mathrm{mmol})$ in ethyl ether $(30 \mathrm{ml})$ at $16^{\circ} \mathrm{C}$ for $16 \mathrm{~h}$. A similar procedure with the synthesis of $\mathrm{S}_{\mathrm{nf}}$ gave the product in $51 \%$ yield. bp $49.2^{\circ} \mathrm{C} \quad(2.1 \mathrm{mmHg}) . \quad{ }^{1} \mathrm{H}$ $\operatorname{NMR}\left(\mathrm{CCl}_{4}\right) \quad \delta=5.78 \quad\left(\mathrm{q}, \quad 1 \mathrm{H}, \quad J_{1}=1.0 \mathrm{~Hz}\right.$, $\left.J_{2}=11.0 \mathrm{~Hz}, \mathrm{C}=\stackrel{\text { C }}{ }\right), 6.12\left(\mathrm{q}, 1 \mathrm{H}, J_{1}=1.0 \mathrm{~Hz}\right.$, $\underline{\mathrm{H}}$

$\left.J_{2}=18.0 \mathrm{~Hz}, \stackrel{\stackrel{\mathrm{H}}{\mathrm{C}}}{\mathrm{C}}=\stackrel{\prime}{\mathrm{C}}\right)$, and $6.73 \mathrm{ppm}(\mathrm{q}, 1 \mathrm{H}$, $J_{1}=11.0 \mathrm{~Hz}, J_{2}=18.0 \mathrm{~Hz}, \mathrm{C}=\mathbf{C}_{\text {). }}$. H

\section{4-Trimethylsilyl-2,3,5,6-tetrafluorostyrene} $\left(S_{n f} l\right)$

To THF $(64 \mathrm{ml})$ solution of ethylmagnesium bromide (12 mmol), 4-bromo-2,3,5,6-tetrafluorostyrene $(2.79 \mathrm{~g}, 11 \mathrm{mmol})$ was added dropwise at $0^{\circ} \mathrm{C}$, and reacted for $10 \mathrm{~min}$ at room temperature. The reaction was quenched with trimethylchlorosilane $(3.4 \mathrm{ml}, 27 \mathrm{mmol})$. After the usual work-up, distillation gave the product in $51 \%$ yield. bp $64.5^{\circ} \mathrm{C}(0.5 \mathrm{mmHg})$. ${ }^{1} \mathrm{H} \mathrm{NMR}\left(\mathrm{CCl}_{4}\right) \delta=0.49\left(\mathrm{~s}, 9 \mathrm{H}, \mathrm{SiC}_{3}\right), 5.77$ $\left(\mathrm{q}, 1 \mathrm{H}, J_{1}=2.0 \mathrm{~Hz}, J_{2}=11.0 \mathrm{~Hz}, \mathrm{C}=\mathrm{C}^{\prime}\right), 6.17$ $\underline{\mathrm{H}}$

$\left(\mathrm{q}, 1 \mathrm{H}, J_{1}=2.0 \mathrm{~Hz}, J_{2}=17.8 \mathrm{~Hz}, \mathrm{C}=\mathrm{C}\right)$, and H

$6.82 \mathrm{ppm}\left(\mathrm{q}, 1 \mathrm{H}, J_{1}=11.0 \mathrm{~Hz}, J_{2}=17.8 \mathrm{~Hz}\right.$,<smiles>[CH-]=C</smiles>

4-Pentame thyldisiloxanyl-2,3,5,6-tetrafluorostyrene $\left(S_{n f} 2\right)$

4-Vinyltetrafluorophenylmagnesium bromide, synthesized from 4-bromo-2,3,5,6tetrafluorostyrene $(2.49 \mathrm{~g}, 9.8 \mathrm{mmol})$ similarly in the synthesis of $\mathrm{S}_{\mathrm{nf}} 1$, was reacted with pentamethylchlorodisiloxane $(2.05 \mathrm{~g}, 11 \mathrm{mmol})$ at room temperature for $2 \mathrm{~h}$. The usual work- up and column chromatography gave the product in $72 \%$ yield. ${ }^{1} \mathrm{H} \mathrm{NMR}\left(\mathrm{CCl}_{4}\right) \delta=$ $0.16\left(\mathrm{~s}, 9 \mathrm{H}, \mathrm{Si}\left(\mathrm{CH}_{3}\right)_{3}\right)$, and $0.51 \mathrm{ppm}(\mathrm{t}, 6 \mathrm{H}$, $\left.J_{\mathrm{FCSiCH}}=1.5 \mathrm{~Hz}, \quad \mathrm{OSi}\left(\mathrm{CH}_{3}\right)_{2}\right)$. Vinyl protons appeared at identical positions with $\mathrm{S}_{\mathrm{nf}} 1$.

\section{p-Trimethylsilylmethylstyrene (B1)}

$p$-Vinylbenzyl-magnesium chloride, synthesized from activated magnesium (10.2 g, $240 \mathrm{mmol})$ by ethylene dibromide $(1.0 \mathrm{ml})$ and p-chloromethylstyrene $(7.0 \mathrm{~g}, 46 \mathrm{mmol})$ in ether $(180 \mathrm{ml})$ at room temperature, was reacted with trimethylchlorosilane $(12.3 \mathrm{ml}, 97 \mathrm{mmol})$ under gentle reflux of the solvent. The reaction system was destroyed with aq. $\mathrm{NH}_{4} \mathrm{Cl}$, and the organic layer was collected. Column chromatography gave the product in $76 \%$ yield. ${ }^{1} \mathrm{H}$ $\operatorname{NMR}\left(\mathrm{CCl}_{4}\right) \delta=0.14\left(\mathrm{~s}, 9 \mathrm{H}, \mathrm{SiC}_{3}\right), 2.16$ (s, $\left.2 \mathrm{H}, \quad \mathrm{CH}_{2}\right), 5.17 \quad\left(\mathrm{q}, \quad 1 \mathrm{H}, \quad J_{\mathrm{i}}=2.0 \mathrm{~Hz}\right.$, $\left.J_{2}=11.0 \mathrm{~Hz}, \mathrm{C}=\mathrm{C}^{\prime}\right), 5.67\left(\mathrm{q}, 1 \mathrm{H}, J_{1}=2.0 \mathrm{~Hz}\right.$,

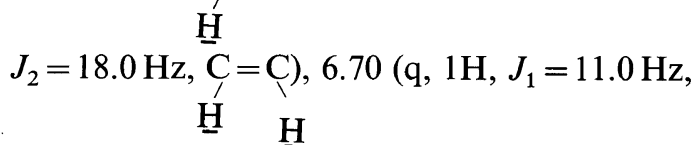

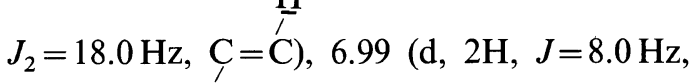
$\left.-\mathrm{CH}_{2}\right)$,

p-Pentamethyldisiloxanylmethylstyrene (B2)

$p$-Vinylbenzylmagnesium chloride (240 mmol) was added dropwise to dimethyldichlorosilane $(30 \mathrm{ml}, 247 \mathrm{mmol})$ in $\mathrm{THF}$ $(200 \mathrm{ml})$ during $4 \mathrm{~h}$ at room temperature to $40^{\circ} \mathrm{C}$. After removal of excess dimethyldichlorosilane, the reaction product was again dissolved in THF $(100 \mathrm{ml})$ and reacted with LTMS $(240 \mathrm{mmol})$. The usual work-up and column chromatography gave the product in $70 \%$ yield. ${ }^{1} \mathrm{H}$ NMR $\delta=0.13(\mathrm{~s}, 15 \mathrm{H}$, $\left.\mathrm{SiC}_{3}\right)$, and $2.17 \mathrm{ppm}\left(\mathrm{s}, 2 \mathrm{H}, \mathrm{CH}_{2}\right)$. 
p-Heptamethyltrisiloxan-1-ylmethylstyrene (B3)

1,5-Dichlorohexamethyltrisiloxane $(71.0 \mathrm{~g}$, $256 \mathrm{mmol})$ was treated succesively with $p$ vinylbenzylmagnesium chloride $(46 \mathrm{mmol})$ and methyllithium or methylmagnesium bromide $(46 \mathrm{mmol})$, similarly to the synthesis of B2. The usual work-up and purification by column chromatography gave the product in $50 \%$ yield. ${ }^{1} \mathrm{H}$ NMR $\delta=0.10,0.12,0.13$ (three s, $\left.21 \mathrm{H}, \mathrm{SiC}_{-}\right)$, and $2.17 \mathrm{ppm}\left(\mathrm{s}, 2 \mathrm{H}, \mathrm{C}_{2}\right)$.

\section{p-Nonamethyltetrasiloxan-1-ylmethylstyrene (B4)}

End-capping the reaction mixture by LTMS in place of methyllithium or methylmagnesium bromide in the synthesis of $\mathrm{B} 3$ gave $\mathrm{B} 4.45 \%$ yield. ${ }^{1} \mathrm{H}$ NMR $\delta=0.13$ (s, 27H, $\mathrm{SiCH}_{3}$ ), and $2.17 \mathrm{ppm}\left(\mathrm{s}, 2 \mathrm{H}, \mathrm{C}_{2}\right)$.

p-Undecamethylpentasiloxan-1-ylmethylstyrene

(B5)

End-capping the reaction product between LTMS and $\mathrm{D}_{3}$ by the chlorosilane from $p$ vinylbenzylmagnesium chloride and dimethyl- dichlorosilane, similarly to the synthesis of S5, gave $\mathrm{B} 5$ in $48 \%$ yield. ${ }^{1} \mathrm{H}$ NMR $\delta=0.13$ (s, $\left.33 \mathrm{H}, \mathrm{SiC}_{3}\right)$, and $2.17 \mathrm{ppm}\left(\mathrm{s}, 2 \mathrm{H}, \mathrm{C}_{2}\right)$.

\section{RESULTS AND DISCUSSION}

The chain length of the monomers S5, Sn, M5, Mn, and B5 could be regulated by controlling the ring-opening reaction of $\mathrm{D}_{3}$. However, monomers S8 and M8 could not be selectively synthesized by this method, because the ring-opening reaction of two moles of $\mathrm{D}_{3}$ by LTMS gave a statistical product distribution. These monomers and S2, S3, S4, M2, $\mathrm{SF} 2, \mathrm{FF} 2, \mathrm{FS} 2, \mathrm{~S}_{\mathrm{nf}} 2, \mathrm{~B} 2, \mathrm{~B} 3$, and B4 were synthesized by stepwise coupling of suitable intermediates.

In the synthesis of $p$-vinylphenylmagnesium chloride, it was realized that effective mixing is very important in smooth and efficient formation of the Grignard reagent. This was also found to be true in the synthesis of Mn macromer. Here, brief comments on ultrasonic irradiation on the syntheses of $p$-vinyl-

Table I. Effects of ultrasonic irradiation on the functionality of polysiloxane macromers ${ }^{a}$

\begin{tabular}{|c|c|c|c|c|c|c|c|}
\hline \multirow{3}{*}{ No. ${ }^{b}$} & \multirow{3}{*}{$\frac{\mathrm{D}_{3}}{\mathrm{moll}^{-1}}$} & \multirow{3}{*}{$\frac{\text { LTMS }}{\mathrm{moll}^{-1}}$} & \multicolumn{5}{|c|}{ Macromer } \\
\hline & & & Yield & & & & \\
\hline & & & $\%$ & $M_{n}$, calcd & $\begin{array}{c}M_{n}, U V \\
\quad \times 10^{3}\end{array}$ & $M_{n}, \mathrm{VPO}$ & $f^{\mathrm{c}}$ \\
\hline S-1 & 0.911 & 0.0633 & 79 & 3.0 & 2.8 & 3.0 & 1.07 \\
\hline S-2 & 0.613 & 0.0405 & 80 & 3.3 & 3.4 & 3.5 & 1.03 \\
\hline S-3 & 0.651 & 0.0217 & 85 & 6.3 & 6.7 & 5.9 & 0.88 \\
\hline$S-3 U^{d}$ & 0.651 & 0.0217 & 85 & 6.3 & 6.6 & 5.9 & 0.89 \\
\hline M-1 & 1.00 & 0.0289 & 94 & 8.0 & 7.6 & 5.5 & 0.72 \\
\hline $\mathrm{M}-2 \mathrm{U}$ & 0.534 & 0.0328 & 76 & 3.9 & 3.7 & 3.8 & 1.03 \\
\hline M-3 & 1.04 & 0.0433 & 83 & 5.7 & 6.4 & 5.4 & 0.84 \\
\hline M-4U & 0.779 & 0.0280 & 90 & 6.5 & 6.2 & 6.2 & 1.00 \\
\hline M-5 & 0.904 & 0.0768 & 60 & 2.9 & 3.9 & 3.5 & 0.90 \\
\hline M-6U & 0.752 & 0.0278 & 90 & 5.6 & 5.6 & 5.6 & 1.00 \\
\hline
\end{tabular}

a Polymerizations were carried out at $0^{\circ} \mathrm{C}$ in $\mathrm{THF}$, and terminated with three-fold excess $\mathrm{SSiCl}$ (S-series) or $\mathrm{MSiCl}$ (M-series).

${ }^{\mathrm{b}} \mathrm{U}$ indicates the reaction under ultrasonic irradiation in the terminating step.

c $f=M_{n}, \mathrm{VPO} / M_{n}, \mathrm{UV}$.

d Functionalization by $\mathrm{SSiCl}$ was satisfactory as long as the concentration of LTMS was kept higher than about $0.03 \mathrm{moll}^{-1}$, and no significant effect of ultrasonic irradiation was observed. 


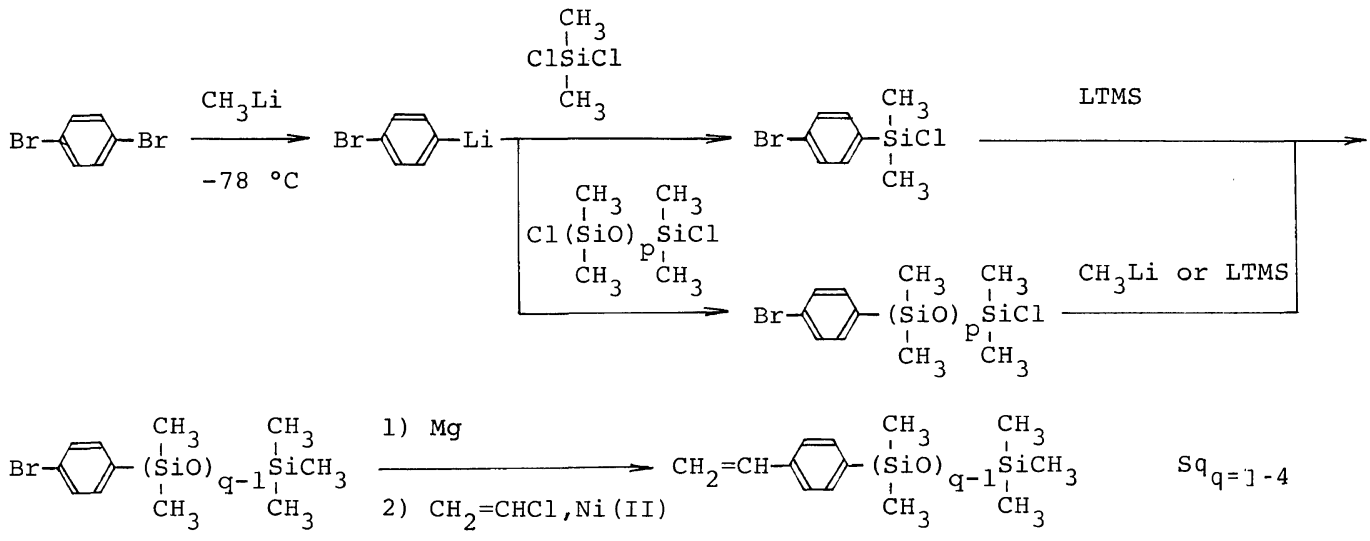

Scheme 5. Alternative route to S1-S4.

Table II. Polymerization and copolymerization of vinyl-polymerizable oligoorganosiloxane monomers ${ }^{\mathrm{a}}$

\begin{tabular}{|c|c|c|c|c|c|c|c|c|c|c|c|}
\hline \multirow{2}{*}{ No. } & \multicolumn{3}{|c|}{ Feed } & \multirow{2}{*}{$\frac{\text { Yield }}{\%}$} & \multicolumn{2}{|c|}{ Composition $^{\mathbf{b}}$} & \multirow{2}{*}{$\begin{array}{l}M_{w}^{c} \\
\times 10^{4}\end{array}$} & \multirow{2}{*}{$M_{w} / M_{n}$} & \multirow{2}{*}{$\frac{\text { Siloxane }^{d}}{w t \%}$} & \multirow{2}{*}{$\begin{array}{l}\text { Silicon }^{\mathrm{e}} \\
\text { number }\end{array}$} & \multirow{2}{*}{$\begin{array}{l}\text { Appear- } \\
\text { ance }^{\mathrm{f}}\end{array}$} \\
\hline & $\mathrm{M}_{1} / \mathrm{wt} \%$ & $\mathbf{M}_{2} / \mathrm{wt}$ & $t \%$ & & $M_{1} / w t \%$ & $\mathbf{M}_{2} / w t^{\circ} \%$ & & & & & \\
\hline 1 & $\mathrm{~S} 1,100$ & - & & 96 & $\mathrm{~S} 1,100$ & - & 21.7 & 2.11 & 41 & 1.0 & $\mathrm{~s}$ \\
\hline 2 & S1, 73 & S5, & 27 & 96 & $\mathrm{~S} 1,75$ & S5, 25 & 28.1 & 2.73 & 50 & 1.4 & s \\
\hline 3 & $\mathrm{~S} 1, \quad 53$ & S5, & 47 & 94 & $\mathrm{~S} 1,53$ & S5, 47 & 49.0 & 3.77 & 58 & 2.0 & s \\
\hline 4 & $\mathrm{~S} 1, \quad 70$ & S94, & 30 & 91 & S1, 75 & S94, 25 & 30.8 & 2.14 & 58 & 2.0 & s \\
\hline 5 & $\mathrm{~S} 1, \quad 53$ & S94, & 47 & 94 & S1, 56 & S94, 44 & 55.2 & 2.95 & 67 & 2.8 & s \\
\hline 6 & $\mathrm{~S} 2,100$ & - & & 90 & $\mathrm{~S} 2,100$ & - & 21.7 & 2.67 & 59 & 2.0 & s \\
\hline 7 & $\mathrm{~S} 2, \quad 40$ & SF2, & 60 & 80 & $\mathrm{~S} 2, \quad 41$ & SF2, 59 & 26.2 & 1.86 & 64 & 2.0 & w \\
\hline 8 & $\mathrm{~S} 2, \quad 50$ & $\mathrm{~S}_{\mathrm{nf}}$ & 50 & 98 & $\mathrm{~S} 2, \quad 50$ & $\mathrm{~S}_{\mathrm{nf}}, \quad 50$ & 29.6 & 2.05 & 30 & 0.9 & $\mathrm{~s}$ \\
\hline 9 & S2, 79 & St4, & 21 & 70 & S2, 76 & St $4, \quad 24$ & 16.0 & 2.45 & 62 & 2.5 & $\mathrm{~s}$ \\
\hline 10 & $\mathrm{~S} 2, \quad 74$ & $\mathrm{FA}$ & 26 & 71 & $\mathrm{~S} 2, \quad 73$ & FA, $\quad 26$ & 2.5 & 2.80 & 43 & 1.7 & $w$ \\
\hline 11 & $\mathrm{~S} 2, \quad 55$ & FA, & 45 & 50 & S2, 54 & FA, 45 & 7.5 & 2.83 & 32 & 1.4 & $\mathrm{w}$ \\
\hline 12 & $\mathrm{~S} 2, \quad 24$ & FA, & 76 & 80 & $\mathrm{~S} 2, \quad 33$ & FA, 67 & 16.5 & 2.47 & 19 & 1.0 & w \\
\hline 13 & $\mathrm{~S} 3,100$ & - & & 71 & $\mathrm{~S} 3,100$ & - & 78.1 & 2.14 & 68 & 3.0 & $\mathrm{w}$ \\
\hline 14 & S3, 90 & $\mathrm{St}$ & 10 & 40 & S3, 91 & St, $\quad 9$ & 68.3 & 1.90 & 62 & 2.3 & w \\
\hline 15 & S3, 79 & $\mathrm{St}$ & 21 & 68 & S3, 76 & St, 24 & 53.3 & 1.93 & 52 & 1.5 & $\mathrm{~s}$ \\
\hline 16 & St4, 100 & - & & 67 & St4, 100 & - & 14.0 & 3.26 & 74 & 4.0 & $\mathrm{~s}$ \\
\hline 17 & S5, 100 & - & & 94 & S5, 100 & - & 34.9 & 3.64 & 78 & 5.0 & $w$ \\
\hline 18 & S5, 75 & $\mathrm{St}$ & 25 & 64 & S5, 74 & St, 26 & 15.6 & 2.14 & 58 & 2.0 & $w$ \\
\hline 19 & S5, 53 & $\mathrm{St}$, & 47 & 73 & S5, 53 & St, 47 & 31.7 & 4.90 & 41 & 1.0 & $\mathrm{~s}$ \\
\hline 20 & $\mathrm{~S} 5, \quad 50$ & $\mathrm{FA}$ & 50 & 78 & S5, 53 & FA, 47 & 6.6 & 3.14 & 41 & 3.0 & w \\
\hline 21 & S8, 100 & - & & 90 & $\mathrm{~S} 8,100$ & - & 12.8 & 2.00 & 85 & 8.0 & o \\
\hline 22 & S8, 69 & $\mathrm{St}$ & 31 & 38 & S8, 67 & St, 33 & 5.1 & 1.88 & 57 & 1.8 & $\mathrm{w}$ \\
\hline 23 & S8, 49 & $\mathrm{St}$ & 51 & 58 & $\mathrm{~S} 8, \quad 50$ & St, 50 & 13.4 & 2.51 & 43 & 1.0 & $\mathrm{~s}$ \\
\hline 24 & S94, 59 & St, & 41 & 69 & S94, 57 & St, 43 & 60.1 & 2.67 & 57 & 1.8 & s \\
\hline 25 & S94, 42 & $\mathrm{St}$ & 58 & 11 & S94, 39 & St, 61 & 23.7 & 2.66 & 39 & 0.9 & $s$ \\
\hline 26 & $\mathrm{~S}_{\mathrm{nf}}, 100$ & - & & 56 & $S_{n f}, 100$ & - & 11.8 & 1.57 & - & - & s \\
\hline 27 & $S_{n f} 1,100$ & - & & 82 & $S_{n f} 1,100$ & - & 19.3 & 2.91 & 30 & 1.0 & s \\
\hline 28 & $\mathrm{~S}_{\mathrm{nf}} 2,100$ & - & & 67 & $\mathrm{~S}_{\mathrm{nf}} 2,100$ & - & 50.2 & 2.82 & 46 & 2.0 & s \\
\hline 29 & $\mathrm{~F} 1,100$ & - & & 60 & $F 1,100$ & - & 18.5 & 2.01 & 38. & 1.0 & s \\
\hline 30 & FS2, 100 & - & & 56 & FS2, 100 & - & 31.0 & 1.96 & 69 & 2.0 & $\mathrm{~s}$ \\
\hline 31 & $\mathrm{FF} 2,100$ & - & & 68 & $\mathrm{FF} 2,100$ & - & 37.3 & 2.12 & 75 & 2.0 & $\mathrm{w}$ \\
\hline 32 & $\mathrm{SF} 2,100$ & - & & 78 & $\mathrm{SF} 2,100$ & - & 29.7 & 1.84 & 69 & 2.0 & $\mathrm{w}$ \\
\hline
\end{tabular}


Oxygen Permeable Membrane

Table II. continued

\begin{tabular}{|c|c|c|c|c|c|c|c|c|c|c|}
\hline \multirow{2}{*}{ No. } & \multicolumn{2}{|c|}{ Feed } & \multirow{2}{*}{$\frac{\text { Yield }}{\%}$} & \multicolumn{2}{|c|}{ Composition $^{\mathrm{b}}$} & \multirow{2}{*}{$\begin{array}{l}M_{w}^{c} \\
\times 10^{4}\end{array}$} & \multirow{2}{*}{$M_{w} / M_{n}$} & \multirow{2}{*}{$\frac{\text { Siloxane }^{d}}{w t^{\circ} \%}$} & \multirow{2}{*}{$\begin{array}{l}\text { Silicon }^{\mathrm{e}} \\
\text { number }\end{array}$} & \multirow{2}{*}{$\begin{array}{l}\text { Appear } \\
\text { ance }^{f}\end{array}$} \\
\hline & $\mathrm{M}_{1} / \mathrm{wt} \%$ & $\mathrm{M}_{2} / \mathrm{wt} \%$ & & $\mathrm{M}_{1} / \mathrm{wt} \%$ & $\mathbf{M}_{2} / \mathrm{wt} \%$ & & & & & \\
\hline 33 & B1, 100 & - & 36 & B1, 100 & 一 & 83.0 & 1.78 & 46 & 1.0 & $\mathrm{~s}$ \\
\hline 34 & B2, 100 & - & 60 & $\mathrm{~B} 2,100$ & - & 56.4 & 2.68 & 61 & 2.0 & $\mathrm{w}$ \\
\hline 35 & B2, 93 & St, 7 & 62 & B2, 95 & St, $\quad 5$ & 49.2 & 1.86 & 58 & 1.8 & $\mathrm{w}$ \\
\hline 36 & B2, 85 & St, 15 & 52 & B2, 83 & St, 17 & 52.2 & 1.81 & 51 & 1.3 & $\mathrm{~s}$ \\
\hline 37 & MS3, 15 & FA, 85 & 84 & MS3, 16 & $\mathrm{FA}, \quad 84$ & - & - & 13 & 0.5 & w \\
\hline 38 & M5, 100 & - & 89 & M5, 100 & - & 24.2 & 2.87 & 70 & 5.0 & o \\
\hline 39 & M5, 90 & St, 10 & 58 & M5, 88 & St, 12 & 12.5 & 1.55 & 62 & 3.0 & o \\
\hline $40^{\mathrm{f}}$ & M5, 80 & St, 20 & 56 & M5, 80 & St, 20 & 43.0 & 1.97 & 56 & 2.2 & o \\
\hline 41 & M5, 70 & $\mathrm{St}, \quad 30$ & 58 & M5, 70 & $\mathrm{St}, \quad 30$ & 7.9 & 1.83 & 49 & 1.6 & o \\
\hline 42 & M5, 50 & St, 50 & 52 & M5, 50 & St, 50 & 7.1 & 1.81 & 35 & 0.9 & o \\
\hline 43 & M5, 47 & FA, 53 & 90 & M5, 47 & FA, 53 & 17.6 & 2.23 & 33 & 2.8 & o \\
\hline 44 & M5, 13 & FA, 87 & 88 & M5, 12 & FA, 88 & 10.4 & 2.55 & 8 & 0.7 & o \\
\hline 45 & M60, 50 & MMA, 50 & 60 & M60, 42 & MMA, 58 & 7.8 & 1.84 & 41 & 1.0 & $\mathrm{~s}$ \\
\hline 46 & M60, 50 & St, 50 & 57 & M60, 55 & St, 45 & 5.8 & 1.45 & 53 & 1.6 & s \\
\hline 47 & $\mathrm{M} 120, \quad 50$ & MMA, 50 & 60 & $M 120,42$ & MMA, 58 & 8.4 & 1.46 & 41 & 1.0 & s \\
\hline 48 & M120, 50 & St, 50 & 62 & M120, 53 & St, 47 & 5.3 & 1.79 & 51 & 1.4 & $\mathrm{~s}$ \\
\hline
\end{tabular}

a Polymerizations were carried out at $60^{\circ} \mathrm{C}$ in THF with $0.1-0.2 \mathrm{~mol} \%$ AIBN as an initiator.

b Determined by ${ }^{1} \mathrm{H}$ NMR.

c Determined by GPC correlated to standard polystyrene.

d Weight percent of oligosiloxane substituent in the polymer.

e Number of silicon atoms per monomer unit.

f s, solid; w, waxy; o, oily.

phenylmagnesium chloride and $\mathrm{Mn}$ macromer are made. In the syntheses, the overall yields of macromers $\mathrm{Sn}$ and $\mathrm{Mn}$ were not necessarily satisfactory. ${ }^{2}$ Efforts were made to obtain high and reproducible yields, although the reported ${ }^{2}$ synthetic routes were basically followed. Ultrasonic irradiation, which has been recently recognized effective to enhance especially heterogeneous reactions, ${ }^{10-13}$ was used in the formation of $p$-vinylphenylmagnesium chloride, which is the precursor of the terminating agent $\mathrm{SSiCl}^{2}{ }^{2}$ The yield increased from the reported $51 \%$ (at most) ${ }^{2}$ to $76 \%$ (reproducible). Ultrasonic irradiation was also effective in obtaining expected functionality of $\omega$-methacrylyl macromer $\mathrm{Mn}$. The results are shown in Table I.

The order of introduction of siloxane side chain and vinyl group can be reversed if it is favorable. For instance, the monomers $\mathrm{S} 1-\mathrm{S} 4$ can be synthesized according to Scheme 5 .
The cross-coupling reactions of $p$ oligoorganosiloxane substituted phenyl grignard reagents with vinyl chloride go rather nicely when the siloxane chain is short. However, the efficiency of the introduction of vinyl group ${ }^{13}$ became low with increasing chain length. In the synthesis of S3, the compound was formed in $83 \%$ selectivity along with $13 \%$ uncoupled product 1-phenylheptamethyltrisiloxane. It was necessary to separate the products by careful column chromatography.

The results of the polymerizations are shown in Table II. Homopolymers are generally waxy or oily except for those containing less than two silicon atoms per monomer unit, and polySt4. Especially, those of methacrylate type polymers lacking in film forming properties. In order to improve the film forming property, copolymerizations with styrene, methyl methacrylate, or FA were carried 
out, and the result are shown in the table. Some graft copolymers were also synthesized. The copolymer composition are very close to those in feed. These results indicate the reactivities of the oligosiloxane substituted styrenes or methacrylates, including macromers, are very close to that of styrene or methyl methacrylate itself, at least in copolymerization reactions. Similar results have been reported by other authors, too. ${ }^{14-17}$ It is of interesting that regarding the reactivity of macromers, the methacrylate type macromer seems to have higher reactivity toward styrene than methyl methacrylate. The effects of polymerizable functional group ${ }^{18}$ and solvent system $^{19}$ on the reactivity of macromers have been reported.

Although the difference in molecular weight must be considered, the copolymers of $\mathrm{Sn}$ monomers having more silicon atoms than two per monomer unit were waxy, and still lacked in self-supporting properties. The copolymers tend to be waxy or oily even with lower siloxane content compared with homopolymers. Graft copolymers of S94 which contain less than two silicon atoms per monomer unit were solid. Fluorine containing polymers $\left(\mathrm{S}_{\mathrm{nf}}\right)$ were solid. The difference in appearance seems to be closely related to $T_{\mathrm{g}}$ of the polymers. The change of $T_{\mathrm{g}}$ is shown in Figure 2 and Table III along with that of $\operatorname{poly}(p-$ alkylstyrene)s.

$T_{\mathrm{g}}$ of polyS1 was found at $136^{\circ} \mathrm{C}$. Such high $T_{\mathrm{g}}$ was also found with poly[ $p$-( $t$-butyl)styrene] $\left(T_{\mathrm{g}}=130^{\circ} \mathrm{C}\right)$ in which bulky $t$-butyl groups are attached to $p$-positions of polystyrene. The difference in $T_{\mathrm{g}}$ of these two polymers may be attributed not only to the difference in the size of the two substituents, but also to the difference in bonding nature of the substituents. In polyS1, the bulky trimethylsilyl groups are attached directly to aromatic rings. In such systems, a $\mathrm{d} \pi-\mathrm{p} \pi$ interaction between silicon atom and aromatic ring would partially restrict the rotation of trimethylsilyl group. Such rotationally restricted large substituents will

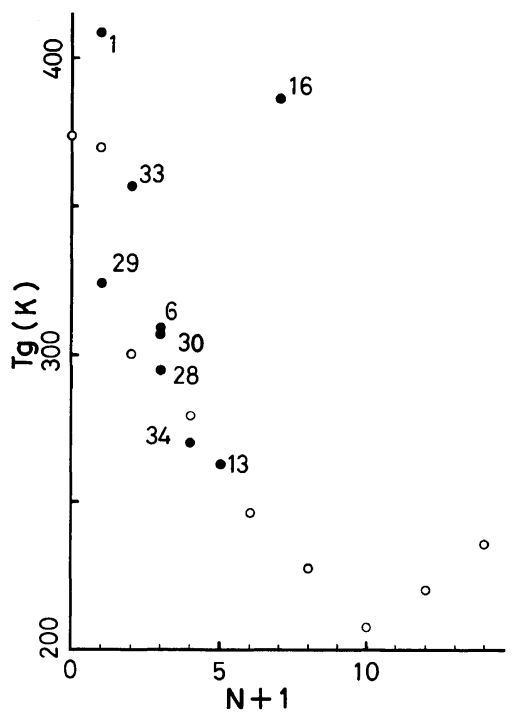

Figure 2. Change in glass transition temperature of poly( $p$-substituted styrene)s with the change of the length of side chain. - poly(p-oligosiloxanylstyrene); $\bigcirc$, $\operatorname{poly}(p$-alkylstyrene); $\mathrm{n}$, number of spacer atoms along the chain between trimethylsilyl (O) or methyl (O) and aromatic ring. Numbers in the figure are same with those in Table II. PolySt4 was plotted at the same $\mathrm{N}$ value with polyS4.

Table III. Glass transition temperatures of selected polymers

\begin{tabular}{rlr} 
& & \\
No & \multicolumn{1}{c}{ Sample } & $T_{\mathrm{g}}$ \\
\cline { 3 - 3 } & & ${ }^{\circ} \mathrm{C}$ \\
\hline 1 & PolyS1 & 136 \\
6 & PolyS2 & 36 \\
13 & PolyS3 & -10 \\
16 & PolySt4 & 114 \\
33 & PolyB1 & 85 \\
34 & PolyB2 & -3 \\
29 & PolyF1 & 52 \\
30 & PolyFS2 & 34 \\
28 & PolyS 2 & 22 \\
2 & Copoly[S1-S5 (73-27)] & 90 \\
3 & Copoly[S1-S5 (53-47)] & 51 \\
19 & Copoly[S5-St $(53-47)]$ & 18 \\
25 & Copoly[S94-St(42-58)] & 86 \\
4 & Copoly[S94-S1(30-70)] & 101 \\
5 & Copoly[S94-S1(47-53)] & 73 \\
\hline
\end{tabular}

make the movement of polymer back bone more difficult compared with poly $[p-(t-$ butyl)styrene] resulting in higher $T_{\mathrm{g}}$ of polyS1 
than poly[ $p$-( $t$-butyl)styrene $]$. Such speculation seems to be supported by the fact that polyB1, which has larger substituents than polyS1, shows much lower $T_{\mathrm{g}}\left(85^{\circ} \mathrm{C}\right)$ compared with polyS1. In polyB1, the bulky trimethylsilyl groups are not directly attached to aromatic rings, and thus lose the $\mathrm{d} \pi-\mathrm{p} \pi$ interaction. The free rotation of the substituents will reduce the resistance of the movement of polymer back bone, resulting in lower $T_{\mathrm{g}}$. In case of polySt 4 in which tetrasiloxane is attached to $p$-position of polystyrene as a compact branched form, the $T_{\mathrm{g}}\left(114^{\circ} \mathrm{C}\right)$ is much higher than that of polyS4 $\left(<-30^{\circ} \mathrm{C}\right)$ in which tetrasiloxane is attached as a linear chain. The entropy change in glass transition will be larger for polyS4 than polySt4, resulting in lower $T_{\mathrm{g}}$ of polyS4. The silicon atom directly attached to the aromatic nuclei may also reduce the flexibility of the bulky tetrasiloxane substituents. Introduction of disiloxane chain at the para position of polystyrene lowered the $T_{\mathrm{g}}$ of back bone polymer $\left(T_{\mathrm{g}} \quad 100^{\circ} \mathrm{C}\right)$ sharply and dramatically $\left(T_{\mathrm{g}}=36^{\circ} \mathrm{C}\right)$. PolyB2 has even lower $T_{\mathrm{g}}\left(-3^{\circ} \mathrm{C}\right)$. Introduction of longer siloxane chain than trisiloxane lowered the $T_{\mathrm{g}} \mathrm{s}$ too much; consequently, the polymers lack self-supporting properties.

The difference between polysiloxane and polymethylene side chains lies in that the latter can crystallize when the chain length -becomes longer than about 10 methylene units and the $T_{\mathrm{g}}$ goes up with increasing methylene units of more than 10 .

The $T_{\mathrm{g}} \mathrm{s}$ of polyS2, S3, B2, FS2, $\mathrm{S}_{\mathrm{nf}} 2$ and the copolymers 2, 3, 19 in Table III were found between those of copolymer component homopolymers and they were much lower than that of polystyrene itself, a fact which suggests homogeneous distribution of the short siloxane chains. Although the $T_{\mathrm{g}} \mathrm{s}$ of the graft copolymers (No. 2,3,19 in Table III) were also found between those of back bone and branch components, the decrease in $T_{\mathrm{g}}$ was much smaller than that of polymers with short siloxane chains, which suggests an incomplete

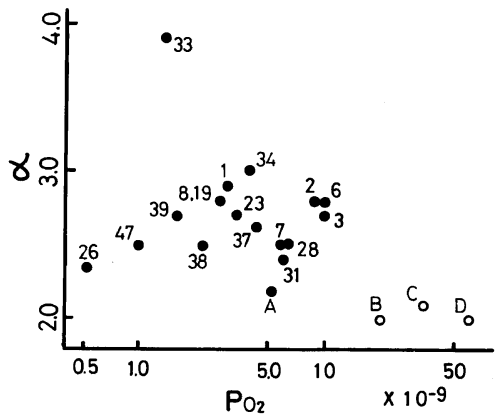

Figure 3. Oxygen permeation behavior of the polymer films. $P_{\mathrm{O}_{2}}$ in $\mathrm{cm}^{3}(\mathrm{STP}) \cdot \mathrm{cm}^{-1} \mathrm{~cm}^{-2} \cdot \mathrm{s}^{-1} \cdot \mathrm{cmHg}^{-1}$. Numbers in the figure are the same as those in Table II. A, polyFA; B, copoly(bisphenol A carbonate- $b$-dimethylsiloxane); ${ }^{6} \quad$ C, $p$-Hydroxyphenol cross-linked PDMS ${ }^{7}$ D, PDMS.

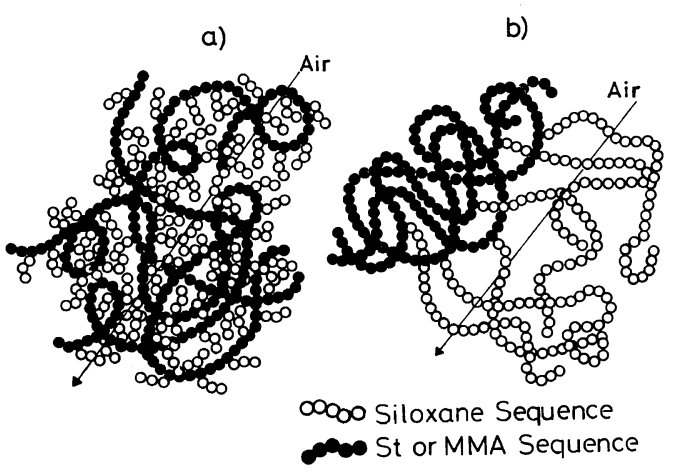

Figure 4. Imaginative gas permeation scheme through shortbranched(non phase-separated) and long-branched or block(phase-separated) polymer films. a) shortbranched; b) long-branched.

phase separated structure of these graft copolymers. A more detailed study is necessary to clarify the miscibility of the back bone and branch components.

The results of oxygen permeation determined by the gas chromatographic method are shown in Figure 3. The polymers generally showed permeation constants in the order of $10^{-9} \mathrm{~cm}^{3} \mathrm{~cm}^{-1} \mathrm{~s}^{-1} \mathrm{~cm}^{-2} \mathrm{cmHg}^{-1}$, and selectivity of 2.5 . Among them, polyS2 and polyB1 showed $P_{\mathrm{O}_{2}}=5.0 \times 10^{-9}, \quad 1.4 \times 10^{-9}$ and $\alpha=2.8,3.9$, respectively. The selectivities are much higher than the commercialized block or cross-linked polymers. Longer siloxane side chain branched copolymers containing similar 
amounts of siloxane units with homopolymers showed lower selectivity. Although a detailed discussion will be made in a future article, the selectivity in permeation through polyS2 at $5^{\circ} \mathrm{C}$ (lower than the $T_{\mathrm{g}}$ of the polymer) was 3.2. The selectivity was even higher at lower temperature. Accordingly, the difference in selectivity in permeation between polyS 2 and long polysiloxane branched graft copolymers is not considered to be because of the difference in state of the polymer, but, at present, it is considered to be because of the effect of the micro phase separation. The phenomena described above suggest the following speculation as an imaginative effects of polymer back bone on permeation as shown in Figure 4. In the long branched polymers, the siloxane chains are basically phase-separated from the back bone components, and gases permeate through the phase-separated PDMS domain, accordingly, the $P_{\mathrm{O}_{2}}$ and $\alpha$ are quite similar to those of PDMS itself. In the short siloxane branched comb polymers, the short siloxane branches are distributed, presumably, homogeneously, as suggested by the decrease in $T_{\mathrm{g}} \mathrm{s}$, in the polymer back bone component. By this effects, the $P_{\mathrm{O}_{2}}$ is lowered a little compared with that of PDMS, but the increase in the selectivity in permeation compensates the decrease in permeation constant of such polymers as meterial for oxygen permeable membrane. In the blend systems, such an effect of a hard polymer back bone on permeation cannot be anticipated.

Although it is necessary to carry out more detailed studies to obtain insight on permeation phenomena, homogeneous distribution of short soft components in a hard back bone component which not only works as mechanically supporting component but also exerts selectivity in permeation, seems desirable in designing an oxygen permeable membrane.

\section{REFERENCES}

1. Y. Kawakami, T. Aoki, H. Hisada, Y. Yamamura, and Y. Yamashita, Polym. Commun., 26, 133 (1985).

2. Y. Kawakami, Y. Miki, T. Tsuda, R. A. N. Murthy, and Y. Yamashita, Polym. J., 14, 913 (1982).

3. Y. Kawakami, R. A. N. Murthy, and Y. Yamashita, Polym. Bull., 10, 368 (1983).

4. Y. Kawakami, R. A. N. Murthy, and Y. Yamashita, Makromol. Chem., 185, 9 (1984).

5. Y. Kawakami, T. Aoki, and Y. Yamashita, Macromolecules, in press.

6. W. J. Ward, III, W. R. Browall, and R. M. Salemme, J. Membrane Sci., 1, 99 (1976).

7. S. Asakawa, Y. Saito, M. Kawashito, Y. Ito, S. Tsuchiya, and K. Sugata, National Technical Report, 29, 93 (1983).

8. J. G. Reiss and M. LeBlanc, Angew. Chem. Int. Ed., 17, 621 (1978).

9. J. J. O’Malley, T. J. Pacansky, and W. J. Stauffer, Macromolecules, 10, 1197 (1977); E. W. Bennett, US Patent 3,646,090.

10. J. L. Luche, C. Péfrier, A. L. Gemal, and N. Zikra, $J$. Org. Chem., 47, 3806 (1982).

11. T. J. Mason, J. P. Lorimer, and B. P. Mistry, Tetrahedron Lett., 23, 5363 (1982).

12. B-H. Han and P. Bondjouk, J. Org. Chem., 47, 5030 (1982).

13. Y. Yamawaki, S. Sumi, T. Ando, and T. Hanafusa, Chem. Lett., 379 (1983).

14. R. Milkovich, "Anionic Polymerization. Kinetics, Mechanisms, and Synthesis," J. E. McGrath Ed., ACS Symp. Ser., No. 166, 1981, p 41; R. Milkovich and M. T. Chiong, US Patent 3, 786, 116.

15. K. Ito, N. Usami, and Y. Yamashita, Macromolecules, 13, 216 (1980); Y. Yamashita, K. Ito, H. Mizuno, and K. Okada, Polym. J., 14, 255 (1982).

16. M. Maeda and S. Inoue, Makromol. Chem. Rapid., 2, 537 (1981).

17. M. Takaki, R. Asami, H. Hanahata, N. Sukenaga, and K. Sogawa, Polym. Prepr. Jpn., 30, 860 (1981).

18. R. Asami, M. Takaki, T. Matsuse, and T. Kuwabara, Polym. Prepr. Jpn., 31, 1321 (1982); K. Ito, Y. Masuda, T. Shintani, T. Kitano, and Y. Yamashita, Polym. J., 15, 443 (1983); K. Ito, H. Tsuchida, A. Hayashi, T. Kitano, E. Yamada, and T. Matsumoto, Polm. Prepr. Jpn., 33, 1151 (1984).

19. S. Yamashita, K. Shibatani, K. Takakura, and K. Imai, Kobunshi Ronbunshu, 39, 187 (1982); R. Asami, M. Takaki, K. Sogawa, and Y. Sakaguchi, Polym. Polym, Prepr Jpn., 32, 1115 (1983). 